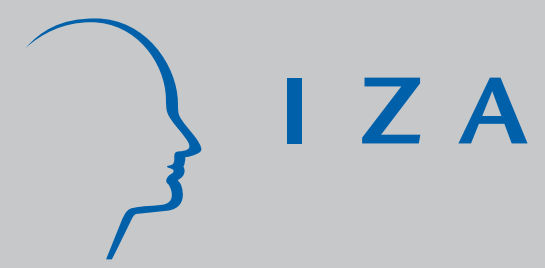

IZA DP No. 8458

On the Intended and Unintended Consequences of Enhanced Border and Interior Immigration Enforcement:

Evidence from Deportees

Catalina Amuedo-Dorantes

Susan Pozo

September 2014

Forschungsinstitut zur Zukunft der Arbeit Institute for the Study of Labor 


\title{
On the Intended and Unintended Consequences of Enhanced Border and Interior Immigration Enforcement: Evidence from Deportees
}

\author{
Catalina Amuedo-Dorantes \\ San Diego State University \\ and IZA \\ Susan Pozo \\ Western Michigan University \\ and IZA
}

Discussion Paper No. 8458

September 2014

IZA

P.O. Box 7240

53072 Bonn

Germany

Phone: +49-228-3894-0

Fax: +49-228-3894-180

E-mail: iza@iza.org

\begin{abstract}
Any opinions expressed here are those of the author(s) and not those of IZA. Research published in this series may include views on policy, but the institute itself takes no institutional policy positions. The IZA research network is committed to the IZA Guiding Principles of Research Integrity.

The Institute for the Study of Labor (IZA) in Bonn is a local and virtual international research center and a place of communication between science, politics and business. IZA is an independent nonprofit organization supported by Deutsche Post Foundation. The center is associated with the University of Bonn and offers a stimulating research environment through its international network, workshops and conferences, data service, project support, research visits and doctoral program. IZA engages in (i) original and internationally competitive research in all fields of labor economics, (ii) development of policy concepts, and (iii) dissemination of research results and concepts to the interested public.
\end{abstract}

IZA Discussion Papers often represent preliminary work and are circulated to encourage discussion. Citation of such a paper should account for its provisional character. A revised version may be available directly from the author. 


\title{
ABSTRACT \\ On the Intended and Unintended Consequences of Enhanced Border and Interior Immigration Enforcement: Evidence from Deportees*
}

\begin{abstract}
Over the past decade, a number of federal and state policies intended to stem the flow of illegal immigration have been implemented. In this paper, we focus on two initiatives: (a) Operation Streamline, as an example of increased border enforcement by the federal government, and (b) state-level omnibus immigration laws, as an illustration of enhanced interior enforcement by state governments. We investigate whether these policies have reduced the intentions of deported immigrants to attempt a new unauthorized crossing. While state-level omnibus immigration laws reduce the proportion of deportees intending to attempt a new crossing, increased border enforcement has proven to be far less effective. In addition, we ascertain human costs associated with these policies. Our findings are mixed in this regard. Noteworthy is how the adoption of more stringent interior enforcement seems to result in a "herding" or "ganging-up" effect whereby the incidence of verbal and physical abuse rises with the number of states enacting such measures. Additionally, our estimates suggest that deportees are more likely to respond that they have risked their lives to cross into the United States as a result of enhanced border enforcement.
\end{abstract}

JEL Classification: F22, K42

Keywords: deportation, interior enforcement, border enforcement, treatment of deportees, re-migration intentions

Corresponding author:

Susan Pozo

Department of Economics

Western Michigan University

Kalamazoo, MI 49008

USA

E-mail: susan.pozo@wmich.edu

\footnotetext{
* We are grateful to several anonymous referees, the Economics Research Department of the Central Bank of Uruguay, participants at the 2012 Population Association Meeting and the 2013 NORFACE Conference and for their comments and suggestions.
} 


\section{Motivation, Objectives and Contributions}

With the onset of the past recession, we observed a heighted sense of animosity toward undocumented immigrants. The charged climate was due, perhaps, to the belief that undocumented immigration was "out of control," adding to the rising competition for scarce jobs. Fiscal and job market pressures led, in turn, to the adoption of various measures intended to reduce the presence of unauthorized immigrants. Broadly speaking, enforcement increased at both border and interior points by federal and by state-level governments. For instance, at the federal level, programs like Operation Streamline (OS) significantly raised the penalties for being apprehended while crossing the border. Before the implementation of OS, it was typically the case that first time unlawful border crossers with no criminal history were simply returned to Mexico. But OS changed that, making it mandatory that all unauthorized crossers be charged with a criminal act and imprisoned (Lydgate 2010). Simultaneously, state governments started to implement policies that dealt with unauthorized migration. This began with the widespread adoption of employment verification (E-Verify) systems, a free web-based program that employers can use to verify that job applicants are eligible to work in the United States. EVerify was soon followed by the enactment of state-level omnibus immigration laws authorizing state and local police to check the immigration status of individuals they had probable cause to arrest. ${ }^{1} \quad$ In some instances, these laws went even further, as in the case of Alabama, where the law required that public school officials check the immigration status of students.

\footnotetext{
${ }^{1}$ Arizona was the first state to pass immigration enforcement laws in April 2010. Five states quickly followed, enacting similar laws in 2011: AL HB56 in June 2011, GA HB87 in May 2011, IN SB590 in May 2011, SC S20 in June 2011 and UT's package (H116, H466, H469 and H497) in March 2011. In 2012, additional states have introduced alike omnibus enforcement bills: Kansas (H2576), Mississippi (H488 and S2090), Missouri (S590), Rhode Island (H7313) and West Virginia (S64). Bills in Mississippi and West Virginia have failed. For more information, visit: http://www.ncsl.org/issues-research/immig/omnibus-immigration-legislation.aspx
} 
At the same time, reports of abuses against immigrants were on the rise (Diaz and Kuhner 2007; Fernandez 2011). Migrant rights' violations ranged from verbal and physical abuse to failure to return personal belongings or inform migrants of their rights. These practices were documented and denounced by the United Nations, the Organization of American States Special Rapporteurs, the Mexican Human Rights Commission, and numerous NGOs (Organization of American States 2003; United Nations 2002). For instance, the Arizona humanitarian aid organization No More Deaths issued two reports: "Crossing the Line" and "A Culture of Cruelty", in which they document more than 30,000 incidents of human rights abuses against undocumented immigrants in short-term detention between fall 2008 and spring 2011 (visit: http://nomoredeaths.org).

These events make us wonder about the intended and unintended consequences of immigration policies as captured by their effectiveness in curbing deportees intent to attempt a new unauthorized crossing as well as the policies' role, if any, in the reported mistreatment of apprehended migrants. We address these two inquiries by examining the effectiveness of increased border enforcement (through the implementation of Operation Streamline (OS)) in curbing undocumented migrants' intent to engage in repetitive unauthorized crossings. Subsequently, we follow up with an exploration of how OS might be impacting the treatment received by deportees during their detention and deportation. Data on approximately 36,000 migrants apprehended while crossing the border from 2005-2012 are used in that analysis. After examining the effect of increased border enforcement, we explore the impact of increased interior immigration enforcement through the enactment of state-level Omnibus Immigration Laws (OIL). How effective are they in curbing undocumented migrants' intent to engage in repetitive unauthorized crossings? How do they impact the treatment received by deportees? 
We address these questions using data on approximately 24,000 illegal immigrants who successfully crossed the border, but were later detained -usually at home, at work, or on the street in interior points, from 2005 and onwards.

At this juncture, it is worthwhile to make a few clarifications. The first clarifications concerns our dependent variables -migrants' intent to cross the border again, in the immediate or more distant future. This intent may or may not translate into a future crossing. However, we have no reason to suspect that migrants will deliberately misstate their intent to cross. Furthermore, while migrants' actual future crossing behavior might ultimately deviate from their stated intent, ideally, if effective, the policy should start by impacting migrants' crossing intentions. As such, learning how increased enforcement is impacting migrants' intent to cross is definitely of interest. A second clarification worth making is the fact that our data refers to deportees. While it would be ideal to ascertain the effects of these polices on the overall intent to migrate illegally by all Mexicans, no survey data currently allow for such an exercise. Nevertheless, examining deportees' crossing intentions can shed some light on how effective increased enforcement is in deterring the repetitive unauthorized crossing of those already exposed to the system. After all, deported individuals have already demonstrated a propensity to migrate. Finally, we should emphasize that our aim is to gauge the impact of tougher immigration policies on undocumented migrants' intent to engage in repetitive unauthorized crossings and on their mistreatment during the detention and deportation process -whether indirectly by altering the type of migrant that chooses to migrate, or directly by impacting the behavior of border patrol agents, interior police agents, or apprehended migrants.

Gaining a better understanding of the intended and unintended consequences of increased immigration enforcement is important for various reasons. Current discussion at the national 
level is pointing to the possibility of comprehensive immigration reform that will include a pathway to citizenship for undocumented immigrants. It has been argued that a path to legalization may increase new unauthorized border crossings. Some legislators have, therefore, been insisting on stepped up immigration enforcement as quid pro quo for a bipartisan compromise on comprehensive immigration reform. But, what do we know about the effectiveness of increased enforcement? Does it curb deportees' recidivism intentions? Does it have any unintended consequences? What are some of the human and social costs of increased immigration enforcement? Our analysis addresses these questions.

If comprehensive immigration reform fails, it is likely that states will continue to enact their own immigration enforcement legislation. In that case, understanding the effectiveness and the unintended human costs of these measures will become particularly important. And even if comprehensive immigration reform succeeds, there might be important lessons to learn from the state-level experiments that may be extended nationwide. Are these measures achieving their goals? What are their unintended costs? Answers will allow policymakers to stand on firmer ground if asked to provide cost/benefit analyses of alternative immigration policies by helping spell out the intended and unintended consequences of record spending on border and interior immigration enforcement at the federal and state levels.

\section{Background}

Immigration enforcement has increased dramatically since the enactment of the 1986 Immigration Reform and Control Act (IRCA). A series of immigration enforcement operations along the U.S.-Mexico border (e.g. Operation Hold-the-Line in El Paso in 1993 and Operation Gatekeeper in San Diego in 1994) resulted in an increasingly fortified border that shifted migration flows to more isolated and dangerous routes, raising migrant fatalities (Massey, 
Durand and Malone 2002). Yet, most apprehended migrants were released back to Mexico after signing a "voluntary departure contract" - a policy that became known as "catch and release", leading to the notion that the border was a "revolving door" (Kossoudji 1992). Voluntary returns were relatively inexpensive for the U.S. government and for the migrant, who avoided a long detention process and a formal removal order. A prolific literature exists examining the impact of these federal policies (e.g. increased border enforcement) on a number of outcomes including unauthorized immigration flows, recidivism and smuggling costs. $^{2}$

Enforcement strategies changed substantially after 9/11 when the Department of Homeland Security (DHS) instituted a consequence delivery system (CDS) intended to increase the cost of immigrating illegally to the United States. The new system ended the "catch and release" practices and provided Border Patrol agents with some latitude for choosing among a number of consequences for offenders. Examples of consequence enforcement actions included Expedited Removals and the Alien Transfer Exit Program (ATEP). ${ }^{3}$ A consequence enforcement action of particular interest to us is Operation Streamline (OS), introduced in 2005 in the Del Rio sector. OS implemented a "Zero Tolerance Policy" that implied that all unauthorized immigrants were subject to criminal prosecution. As shown in Appendix Table A, OS progressively expanded to five more Border Patrol sectors, likely contributing to the $330 \%$

\footnotetext{
${ }^{2}$ Examples of such studies using a variety of data sources -including the Encuesta sobre Migración en la Frontera Norte de México (EMIF), the Encuesta Nacional a Hogares Rurales de Mexico (ENHRUM), the Mexican Migration Project (MMP) or aggregate series on border apprehensions- are the works by Amuedo-Dorantes and Bansak (2012), Angelucci (2012). Bean et al. (1990), Bean, Edmonston, and Passel (1990), Bustamante (1990), Chavez et al. (1990), Cornelius (1989, 1998), Davila et al. (2002), Donato et al. (1992), Espenshade (1990, 1994), Gonzalez de la Rocha and Escobar (1990), Hanson and Spilimbergo (1999), Kossoudji (1992), Massey et al. (1990), Singer and Massey (1988), Orrenius (2001), Orrenius and Zavodny (2003), Ritcher et al. (2007), and White et al. (1990).

${ }^{3}$ Expedited Removals are one example of consequence enforcement actions. They are reserved for individuals captured within 100 miles of the border and within two weeks of illegally entering the country, and effectively eliminate the need for a removal hearing before an immigration judge. They trigger a five year reentry bar on apprehended migrants. The Alien Transfer Exit Program (ATEP), also known as Lateral Repatriation Program, transports undocumented immigrants to points east or west and far from where they were apprehended to make it difficult to reconnect with their coyotes.
} 
increase in the number of prosecutions for first time unauthorized entry (Lydgate 2010). In FY2011, a total of 164,639 people were referred to the U.S. Attorney's office for prosecution (Rosenblum 2012), significantly raising police, jail, criminal justice and legal costs. Hence, it is not surprising that federal spending on immigration enforcement reached $\$ 18$ billion in 2012, exceeding spending by all the other major federal law enforcement agencies combined (Meissner et al. 2013).

Spending on immigration enforcement has also increased at the state level with the passage of state-level Omnibus Immigration Laws (OILs). Following the example of Arizona's SB1070 in 2010, five more states enacted omnibus immigration legislation in 2011 (Alabama (HB56), Georgia (HB87), Indiana (SB590), South Carolina (S20) and Utah (H116, H466, H469 and H497)). Their laws address a variety of topics, including immigration enforcement by local and state police, verification for employment and public benefits and, in some instances, they go even further, requiring schools to verify students' legal status.

A growing number of researchers have turned to examining the impact that these statelevel polices are having on unauthorized immigration levels and on undocumented immigrants themselves. ${ }^{4}$ For instance, Bohn, Lofstrom and Raphael (2014) explore the effects of the 2007 Legal Arizona Workers Act (LAWA). The enactment of LAWA, which mandated the use of an employment verification system for all employers, reduced the share of Hispanic non-citizens -a group more likely to be unauthorized-residing and working in the state of Arizona.

Amuedo-Dorantes and Lozano (Forthcoming) examine the timing and effectiveness of SB1070 in reducing the share of likely unauthorized immigrants in the state, while AmuedoDorantes, Puttitanun and Martinez-Donate (2013) assess how the enactment of E-Verify

\footnotetext{
${ }^{4}$ A comprehensive overview of state and local immigration policy-making in the United States can be found in Varsanyi (2010).
} 
mandates has impacted the migration experience, trajectory and future plans of unauthorized immigrants. They find no evidence of a statistically significant association between E-Verify mandates and the difficulties reported by unauthorized immigrants in accessing a variety of services, including social or government services, finding legal assistance or obtaining health care services. However, the enactment of these mandates infuses deportation fear and reduces inter-state mobility among voluntary returnees during their last migration spell, helping curb deportees' intent to return to the United States in the near future.

Consequence enforcement actions and state-level measures are costly in a variety of respects (Immigration Policy Center 2011). They increase police, jail, criminal justice and legal costs. They impose costs on state agencies, which require additional personnel and time to carry out checks, as well as on schools (possibly losing federal and state funding as enrollments drop), not to mention broader economic costs due to loss of business, decreases in consumer spending and reductions in tax revenues. In addition, there are other nonmonetary costs that have received increased attention, as is the case with reports of mistreatment ranging from physical and verbal abuse to failure to return personal belongings as documented by the United Nations, the Organization of American States Special Rapporteurs, the Mexican Human Rights Commission, and numerous NGOs (Organization of American States 2003; United Nations 2002). More importantly, reports of mistreatment have been on the rise (Diaz and Kuhner 2007; Fernandez 2011).

Despite their monetary costs, we still know very little about the effectiveness of OILs and OS and of their impact, if any, on the mistreatment of detainees. For instance, while Cañas et al. (2012) explore OS's impact on the aggregate number of apprehensions across the Mexico-U.S. border, we still do not know how and if the policy is reducing undocumented migrants' intent to 
re-offend. Furthermore, to date, no studies have looked at one important potential (and presumably unintended) consequence of increased enforcement, as is the case with the objectionable treatment that some undocumented immigrants may be receiving while apprehended and deported to Mexico.

We shed light on these questions by analyzing one of the intended objectives of the policies-as captured by deterred re-entry plans of unauthorized Mexican immigrants. We also analyze unintended consequences - measured by reported mistreatments and life risks- of two immigration enforcement measures: (1) Operation Streamline -an example of increased federal spending on immigration enforcement along the border, and (2) Omnibus Immigration Laws -an illustration of state-level initiatives on interior immigration enforcement.

\section{Data}

We use the Encuesta Sobre Migración en la Frontera Norte de México (EMIF) or Survey on Migration to the Northern Mexican Border in translation. The EMIF is a cross-sectional migration survey, conducted by El Colegio de la Frontera Norte (COLEF) for the Secretaría del Trabajo y Previsión Social and the Consejo Nacional de Población, along the United StatesMexico border (Secretaría del Trabajo y Previsión Social 1998). The EMIF surveys contain a module that is highly representative of the overall population of unauthorized Mexican immigrants apprehended in the United States and returned to Mexico. The survey has been carried out annually in Mexico at the centers where deportees from the United States are delivered by the U.S. immigration authorities. ${ }^{5}$

\footnotetext{
${ }^{5}$ While some deportees were returned to the interior of Mexico through the Mexican Interior Repatriation Program (MIRP), the vast majority of undocumented immigrants were returned to locations along the border located east or west from where they were apprehended through the Alien Transfer Exit Program (ATEP). In fact, the MIRP has been suspended due to cost considerations.
} 
We use data from the 2005-2012 waves, which contain detailed information on the outcomes being examined for approximately 58,000 deportees apprehended at various points in time. ${ }^{6}$ More than half (about 34,000 migrants) were apprehended while crossing the border, with the remainder being detained in the interior of the United States. In many respects, deportees apprehended while crossing the border and those apprehended after having successfully crossed into the United States are similar. However, they differ in other regards. For instance, as displayed in Table 1, 26\% of those apprehended in the interior (successful crossers) speak English. In contrast, only $6 \%$ of those apprehended while crossing do. This might be partially due to the fact that unsuccessful crossers have had shorter or fewer migration spells when compared with their successful counterparts and, thus, fewer opportunities to learn English. Unsuccessful crossers have also relied more often on a coyote to cross relative to migrants who were apprehended in the interior.

\section{<Table 1 about here>}

Of special interest to us is the information on the timing and place of apprehension -both of which are needed to identify whether apprehension took place at a particular Border Patrol sector or in a state with one of the immigration enforcement measures in place. The timing is given by the month and year of the interview, which occurs immediately after deportation. Additionally, the EMIF contains information on place of apprehension. Approximately 58\% of the sample $(33,811$ out of 57,920$)$ was apprehended while crossing the border. Because deportees also indicated the border city through which they were crossing into the United States, we are able to identify the Border Patrol sector in which they were likely captured and, therefore,

\footnotetext{
${ }^{6}$ As noted above, the EMIF is a cross-sectional survey. It does not follow individuals over time.
} 
whether or not it was a Border Patrol sector participating, at that point in time, in OS. ${ }^{7}$ About 58 percent of detained border-crossers were captured in a sector with OS in place.

Individuals apprehended at interior points in the United States, after having successfully crossed the border ( $42 \%$ of our sample of deportees), indicate whether they were apprehended at work, at home, on the street or elsewhere. Sixty-three percent were detained on the street, nine percent at home, $10 \%$ at work and the remaining $18 \%$ elsewhere. In those instances, we use information on the U.S. state where they reported residing to identify whether the state had an OIL in place at the time of apprehension. ${ }^{8}$ About nine percent of deportees captured after having successfully crossed the border were apprehended in a state with an OIL in place.

In addition to the time and place of apprehension, we are interested in information regarding two outcomes: i) deportees intentions to return to the United States ${ }^{9}$ and ii) the treatment received during the apprehension and deportation process. In their responses, they can indicate whether they intend to try a new crossing within the next seven days or at a later date. These responses are used to construct dummy variables identifying the intention to cross illegally ever again, as well as more specifically within the next week. When examining the aggregated sample of individuals apprehended while crossing the border (first columns of Table 1), an overwhelming $88 \%$ of deportees declare intending to cross again. Furthermore, $74 \%$ intend to do so within the next seven days.

When we disaggregate by year, we observe that responses to these questions seem to have been changing over the time period being examined. However, given the relatively short

\footnotetext{
${ }^{7}$ Dates on the implementation of Operation Streamline across the various Border Patrol sectors were obtained from Lydgate (2010). Please refer to Appendix Table A, Panel A.

${ }^{8}$ Dates on the enactment of omnibus immigration legislation were obtained from the National Conference of State Legislators (NCLS) website. See Appendix Table A, Panel B.

${ }^{9}$ Repetitive illegal crossings have traditionally accounted for the largest component of overall apprehensions (Cornelius 1998; Spener 2001).
} 
time span analyzed, we caution against making much of any patterns. Still, an examination of these figures might provide some insights not evident in the overall averages displayed in Table 1. For instance, it is interesting to see in Table 2A how, despite yearly fluctuations, the percentages of deportees apprehended at the border intending to commit recidivism within the next 7 days or ever appear to have fallen from 2005 to 2012. ${ }^{10}$ A similar, perhaps more consistent, picture emerges for deportees apprehended at interior points in Table 2B. For instance, the share of deportees apprehended in states without OILs in place indicating an intent to return within a week appears to have decreased from $85 \%$ in 2005 to $21 \%$ in 2012 , whereas the share expressing an intent to return ever has dropped from $96 \%$ in 2005 to $76 \%$ in $2012 .^{11}$ Still, it is important to stress that these are simply descriptive statistics. They do not account for other factors that may be driving the intent to cross again and, as such, any observed patterns cannot be attributed to specific enforcement policies.

\section{<Tables 2A and 2B about here>}

In addition to inquiring about future migration plans, the EMIF has also been questioning deportees about the treatment received during the apprehension and detention process since 2005. Specifically, respondents are asked whether they were subject to physical aggression by the authorities, such as being pushed or hit; whether they were subject to verbal aggression (yelled at or insulted); and whether their belongings were confiscated. They are also asked whether they were informed of their right to speak with the Mexican Consulate. As can be seen in Tables $2 \mathrm{~A}$ and $2 \mathrm{~B}$, in some instances, the share of immigrants reporting being mistreated does not seem to have appreciably changed in a consistent direction over the years, as in the case of

\footnotetext{
${ }^{10}$ A number of t-tests, available from the authors, suggest that there were statistically significant reductions in the proportion of deportees intending to illegally cross again from the first to the last available survey year.

${ }^{11}$ Once more, differences in the proportion of migrants intending to illegally cross again in the first and last available survey year, are statistically significant at the 5\% level or better. T-tests are available from the authors.
} 
the share of deportees that report being physically abused during the apprehension process. In contrast, the share of deportees indicating having personal property confiscated during their detention process and, for the most part, the share enduring separation from family members, seem to have risen appreciably over time. Lastly, while there appears to be some evidence of widespread failure to inform migrants of their right to contact their consulate, this violation seems to have been addressed, possibly through training. The share of deportees reporting being victims of such a practice has dropped from $86-88 \%$ in 2005 to $25-41 \%$ in $2012 .^{12}$ Still, the summary statistics in Tables $2 \mathrm{~A}$ and $2 \mathrm{~B}$ do not allow us to conclude anything about how these policies and laws have influenced the intent to cross again and how they have impacted the treatment of deportees. To address these questions, we turn to more thorough regression-based modeling that controls for other concurrent determinants of deportees' migratory intentions and treatment received during the apprehension process.

\section{Methodology}

Our first objective is to learn whether increased border enforcement -as captured by the implementation of Operation Streamline (OS) - is deterring deported migrants from intending to return to the United States and how it may be impacting their treatment during the deportation process. To accomplish this aim, we pool individual level data on deportees apprehended while crossing the border from the 2005-2012 waves of the EMIF. The data contain information that allow for the identification of the Border Patrol sector through which migrants crossed, allowing us to ascertain whether or not OS was in place. Specifically, we compare the reported intent to return to the United States by deportees, as well as changes in the circumstances surrounding the

\footnotetext{
${ }^{12}$ T-tests of the statistical significance of these differences are available from the authors.
} 
apprehension process, in treated vs. control Border Patrol sectors pre -vs. post- implementation of OS as follows:

$$
\begin{aligned}
& Y_{i s t}=\alpha_{0}+\alpha_{1} O S_{s t}+\alpha_{2} \# \operatorname{Sec}_{t}+\alpha_{3}\left(\# \operatorname{Sec}_{t} \times O S_{s t}\right)+\gamma^{\prime} X_{i s t}+\delta_{s}+\phi_{t}+\delta_{s} t+\varepsilon_{i s t}, \\
& \varepsilon_{i s t} \sim N(0,1)
\end{aligned}
$$

where: $i=1, \ldots, n$ individuals, $s=$ sector, and $t=$ (month, year). $Y_{i s t}$ equals 1 if the $i$ th deported migrant, who last migrated in time $t$ and was apprehended in Border Patrol sector $s$, indicates: (a) planning on returning to the United States, ${ }^{13}$ or (b) experiencing questionable treatment during the apprehension and detention process. ${ }^{14} O S_{s t}$ is a dummy variable equal to 1 if the migrant was apprehended in a Border Patrol sector with OS in place. For example, $O S_{s t}$ equals 1 if the migrant was apprehended in a treated Border Patrol sector at that time, such as Tucson after January 2008. It is equal to 0 if the migrant was apprehended in the Tucson Border Patrol sector before January 2008, or if s/he was apprehended in a Border Patrol sector that never implemented OS, such as San Diego. In essence, the coefficient on $O S_{s t}$ gauges how OS might have impacted deportees' intent to return to the United States and their treatment during the apprehension process by comparing those two outcomes for deportees crossing through a Border Patrol sector with OS in place and for their remaining counterparts.

To account for the possibility that the impact of OS strengthens (or weakens) as more sectors adopt it, we control for the number of Border Patrol sectors implementing OS (\#Sec $)_{t}$ at the time of apprehension, and interact it with the policy dummy (i.e. $\left.\# S e c_{t} \times O S_{s t}\right)$. It is conceivable, for example, that as the number of Border Patrol sectors implementing OS rises, the

\footnotetext{
${ }^{13}$ We estimate separate models for the "intent to return within the next seven days" and "intent to return in the more distant future".

${ }^{14}$ Separate equations are estimated using responses to questions concerning being physically abused, verbally abused, having possessions confiscated, separated from family, informed of the right to counsel, and risking life.
} 
deterrence effect strengthens due to a tighter "squeeze" on undocumented crossings. Similarly, as the number of sectors under OS increases, it is possible that Border Patrol agents' behavior concerning the treatment of immigrants changes. The interaction term can help us capture these spillover effects.

The vector $\boldsymbol{X}$ includes individual level characteristics traditionally incorporated when modeling migration experiences and decisions, such as gender, race, age, indigenous language, English proficiency, educational attainment, marital status, household head status, and family size. Migration-related characteristics, such as the number of times they have crossed in the past, the number of times they have been deported, the duration of their last migration spell or whether they last crossed with a coyote are also incorporated.

We include a series of Border Patrol sector dummies, time dummies and Border Patrol sector-time trends in equation (1) in order to capture fixed and time-varying regional and macroeconomic factors affecting our outcomes. Border Patrol sector dummies can help capture time invariant geographic characteristics, such as a political environment hostile to immigration -a characteristic that could potentially be related to the likelihood of reporting mistreatment. Border Patrol sector dummies can also capture the presence of networks in specific crossing points $-\mathrm{a}$ trait that can lower migration costs and increase the intent to return to the United States. Time dummies are also incorporated in the model. They help account for economy-wide shocks that could impact the likelihood of mistreatment by affecting investments in police training or the probability of indicating a desire to return to the United States in the future given the economic climate.

The inclusion of Border Patrol sector-specific time trends addresses a key identification assumption in the analysis described above -namely the existence of similar pre-treatment trends 
in treated and control Border Patrol sectors. This assumption is violated if differences between the latter are driving the enactment of the policy, as would be the case if Border Patrol sectors with a growing number of unauthorized entries were more likely to implement OS. To address that possibility, it is important to include Border Patrol sector-specific time trends capturing the overtime variation in apprehensions -a proxy for unauthorized entries. Alternatively, Border Patrol sector-specific time trends might capture changing economic conditions at the Border Patrol sector level, such as the development of migrant businesses -a phenomenon that might lure deportees to the United States.

While our first objective is to explore the effectiveness and impacts of border policy, our second objective is to learn about: (a) the effectiveness of state-level initiatives in immigration enforcement (as captured by the enactment of OILs) in curbing undocumented migrants' intent to engage in repetitive unauthorized crossings, and (b) their impact on the treatment received by deportees when apprehended and detained. To that end, we utilize individual level data on deportees apprehended at work, at home, on the street or elsewhere after having successfully crossed the border from 2005 through 2012. The data contain information on the timing of the apprehension and the state where the migrant resided, allowing us to identify whether a statelevel omnibus immigration law was in place. Our benchmark model is thus given by:

$$
Y_{i s t}=\beta_{0}+\beta_{1} \text { OIL }_{s t}+\beta_{2} \# \text { States }_{t}+\beta_{3}\left(\# \text { States }_{t} \times \text { OIL }_{s t}\right)+\gamma^{\prime} X_{i s t}+\delta_{s}+\phi_{t}+\delta_{s} t+v_{i s t}, \quad v_{i s t} \sim N(0,1)
$$

where $i=1, \ldots, n$ individuals, $s=$ state and $t=$ (month, year). The dependent variable, constructed as a dummy variable, captures the migrant's self-reported intent to return to the United States in the foreseeable future, or whether s/he reported mistreatment during the apprehension and detention process. OIL $\mathrm{O}_{s t}$ equals 1 if the migrant was apprehended in a state with an omnibus 
immigration law at that point in time, such as SB1070 in Arizona, after April 2010; otherwise, it is set equal to 0 . As in the case of OS, we account for spillover effects that could result from the increase in the number of states with OILs by incorporating the variable \#States $t_{t}$ and the interaction term (\# States $_{t} \times$ OIL $_{s t}$ ). Similarly, in addition to the demographic and migratory characteristics in vector $X$ in equation (1), we include state and time dummies as well as statespecific time trends controlling for different trends in state-level characteristics potentially responsible for the adoption of OILs, such as differences in undocumented migration across states. Finally, we include information on whether the deportees, apprehended in the interior, were detained at work, at home or on the street.

Equations (1) and (2) are both estimated as linear probability models (LPMs). LPMs have some potential limitations, including: (a) their linearity assumption, just as with ordinary least squares (OLS); (b) their violation of the homoskedasticity assumption, which can bias standard errors; and (c) the fact that they can yield predicted probabilities that fall outside the unit circle. Despite these limitations, LPMs perform quite well. They impose fewer restrictions on the distribution of the error term by avoiding the normality assumption and, of particular importance for our estimation, they easily converge when working with larger samples (Wooldridge 2008).

\section{Findings}

The results from estimating equations (1) and (2) for the intended and unintended outcomes being examined are reported in Tables 3 through 6 . Table 3 displays the estimated deterrence of OS on deportees' intent to return, while Table 4 informs about the impact of exposure to increased border enforcement on deportees' mistreatment (physical abuse, verbal abuse, confiscation of personal belongings, separation from family members during the 
deportation process, and being uninformed about the right to contact the Mexican consulate). In addition, Table 4 reports on the effect of OS on deportees' likelihood of risking their lives during the crossing. Tables 5 and 6 report on the same outcomes as in Tables 3 and 4, but focusing instead on the effects of interior enforcement. All regressions include time (year, month) dummies, as well as Border Patrol sector or state of apprehension dummies, depending on whether we are examining the impact of OS or OIL, respectively. Border Patrol sector-specific time trends or state of apprehension-specific time trends are also included. The latter are an important check to our model specification, allowing us to control for pre-existing differential trends in treated versus control Border Patrol sectors and states. In what follows, we interpret our findings in terms of marginal effects, thus assuming that all other determinants are held constant. For example, does apprehension in a Border Patrol sector with OS in place deter deportees from intending to attempt a new illegal crossing (i.e. $\left.\frac{\partial r e-m i g r a t e}{\partial o s}\right)$ as presumably intended by the policy?

\section{A) Intended and Unintended Consequences of Operation Streamline}

The estimates in Table 3 address the aforementioned question. Deportees' intent to reoffend does not significantly differ according to whether or not they were detained while crossing through an OS sector. ${ }^{15}$ Similarly, expanding the policy to one more Border Patrol sector has no statistically significant impact on deportees' intent to re-migrate. ${ }^{16}$ In sum, OS

\footnotetext{
${ }^{15}$ Indeed, the estimated impacts - which would be computed as: $\frac{\text { dre-migrate within the week }}{\partial \text { os }}=[0.024+(-0.007 x 6)]$ and $\frac{\text { are-migrate ever }}{\partial O S}=[-0.012+(-0.008 \times 6)]$ in 2012 when six Border Patrol sectors had OS in place, are not statistically different from zero, according to joint significance tests.

${ }^{16}$ The effect on the likelihood of committing recidivism within the week when OS is expanded to one more sector is given by: $\frac{\partial \text { re-migrate within the week }}{\partial \# \text { Hec }}=[-0.028+(-0.007 x O S)]=-0.035$ for deportees captured in a sector with OS in place (i.e. $O S=1$ ) and by -0.028 for the rest. Yet, neither of the two effects is statistically different from zero. Similarly, the effect of expanding OS to one more Border Patrol sector on the likelihood of committing recidivism in the further future is not statistically different from zero for all deportees.
} 
does not seem to significantly shape deportees' intent to return to the United States (commit recidivism) in the short-run or long-run.

\section{<Table 3 about here>}

In addition, apprehension in a Border Patrol sector with OS in place does not significantly increase deportees' likelihood of enduring physical or verbal abuse, having personal property confiscated, being separated from family members or being misinformed about rights to contact the Mexican Consulate (see Table 4). However, we do find that life risks are substantially impacted by OS. In 2012, being apprehended in a sector with OS in place $\left(\frac{\partial \text { life risks }}{\partial \text { OS }}\right)$ raised deportees' life risks by a statistically significant 12.2 percentage points relative to those apprehended in non-OS sectors. Furthermore, we find that expanding OS to one more Border Patrol sector $\left(\frac{\partial \text { life risks }}{\partial \# \text { Sec }}\right)$ increases life risks by a statistically significant 2.4 percentage points among deportees apprehended in sectors with OS in place. These findings are consistent with the idea that crossings are taking place in more remote and dangerous areas on account of the "squeeze" by OS and, overall, corroborate news reports about the human cost of increased border enforcement. ${ }^{17}$ Lastly, the expansion of OS to one more sector along the border is also linked to a statistically significant increase of 9.1 percentage points in the likelihood of enduring family separation $\left(\frac{\partial \text { family separation }}{\partial \# \text { Sec }}\right)$ for crossers using non-OS sectors and to an also statistically significant increase of 8.8 percentage points in that likelihood among deportees apprehended in OS sectors. However, the expansion of OS to more Border Patrol sectors is

\footnotetext{
${ }^{17}$ As noted in the Introduction, these polices might not only increase the risk of crossers, but also alter the profile of crosses. For example, word of stepped up border enforcement could deter the most risk-averse would be migrant, in favor of migrants who are more risk-taking. Alternatively, it could be that more naïve migrants are the ones crossing. While distinguishing among the channels through which increased enforcement operates is of interest, our data cannot differentiate. Rather, we focus on the overall impact of stepped up enforcement, whether via changes in the selection of migrants or via changes in the behavior of the authorities and/or the apprehended migrants.
} 
associated with a lower likelihood of being subject to verbal abuse or being misinformed about one's rights.

\section{<Table 4 about here>}

In addition to our prior findings, the output in Table 4 uncovers several other interesting results. Specifically, deportees with higher levels of education appear more likely to indicate being physically or verbally abused by the border agents than their less educated counterparts. Additionally, deportees who speak English seem to endure a higher likelihood of being separated from family relative to deportees who do not speak the language, possibly signaling that these were migrants with more established roots. It is sobering that migrants who used a coyote are 7.1 percentage points more likely to having risked their lives to cross than migrants who did not use such services. Coyotes might be using less transited and more dangerous routes to avoid detection, and may not hesitate to abandon their clientele when fearing apprehension by the Border Patrol.

B) Intended and Unintended Consequences of state-level Omnibus Immigration Bills

Tables 5 and 6 also inform on the intended and unintended consequences of increased immigration enforcement at the state level -as captured by the enactment of state-level OILs. One difference with regard to the previous model specifications is that these equations include information on the circumstances surrounding apprehension. In the OS estimations, all apprehensions took place at the border, making it unnecessary to account for place of apprehension. But, in the case of the OIL estimations, apprehension could have taken place in a variety of places -at home, at work, on the street or elsewhere (the reference category). Accordingly, we control for the place of apprehension as it may reveal valuable information regarding the circumstances surrounding that event. 
We saw that being detained in a Border Patrol sector with OS in place had no statistically significant effect on deportees' intent to commit recidivism. Are OILs similarly ineffective? Or do OILs deter apprehended undocumented immigrants from planning repetitive unauthorized crossings? According to the results in Table 5, they do have a deterrence effect. In 2012, apprehension in a state with an OIL in place reduced deportees' intent to ever return by about 7.6 percentage points ${ }^{18}$ (from $86 \%$ to approximately $78 \%$ ), compared to apprehension in non-OIL states. The state-level measures are, in particular, effective at curbing deportees' immediate reentry intentions. In 2012, apprehension in an OIL state reduced the intent to return next week by a statistically significant 24 percentage points relative to apprehension in states without OILs.

\section{<Table 5 about here>}

And how does apprehension in a state with an OIL in place affect the incidence of mistreatment with respect to deportees? According to the estimates in Table 6, in 2012 (when 6 states had OILs in place), physical abuse was 0.2 percentage points higher for deportees apprehended in states with an OIL $\left(\frac{\partial \text { pysical abuse }}{\partial O I L}=-0.046+0.008 \times 6=0.002\right)$ relative to their counterparts detained in states without such a law. The statistically significant interaction term reveals that, as more states adopt immigrant legislation, migrants apprehended in states with OILs endure more physical abuse relative to when fewer states had adopted OILs -a pattern suggestive of herding behavior on the part of the authorities.

\section{<Table 6 about here>}

In contrast, in that same year of 2012, verbal abuse was 8 percentage points less likely among deportees apprehended in a state with an OIL in place than among other deportees.

\footnotetext{
${ }^{18}$ In this case $\frac{\partial r e-\text { migrate ever }}{\partial O I L}=[-0.022+(-0.009 \times 6)]=-0.076$, where six is the number of U.S. states with an OIL in place in 2012.
} 
However, the progressive expansion of OILs to other states has the opposite effect, increasing the likelihood of experiencing verbal abuse with each additional state adopting an OIL by 1.6 percentage points among migrants apprehended in states with an OIL in place, and by 1.1 percentage points among their counterparts apprehended elsewhere. ${ }^{19}$ Perhaps, the growing number of states adopting OILs is a reflection of a growing anti-immigrant sentiment that generally manifests itself in a higher incidence of mistreatment. Finally, with 6 states having OILs in place, apprehension in a state with an OIL in place is also linked to a 2.1 percentage points higher likelihood of experiencing family separation in 2012.

While OILs seem to increase some forms of mistreatment, detention in a state with an OIL is associated with a lower incidence of other types of mistreatments. For instance, with 6 OILs in place by 2012, apprehension in an OIL state seemed to lower the incidence of being misinformed about the right to contact the Mexican consulate by 27 percentage points. Similarly, the expansion of OILs to other states is associated with a reduced incidence of this type of violation, especially among those apprehended in a state with an OIL in place. Perhaps, as OILs become more prevalent and receive growing public attention, certain groups publicize migrants' right to counsel. Alternatively, the Mexican government might be responding to public outcries about mishandling of detainees, increasing migrants' awareness of their rights through information campaigns in border cities and through the Mexican government's direct involvement in Mexican deportation cases.

In addition to the effects of OIL enactments, our results provide other insights into the determinants of deportees return intentions and the treatment that they receive. Turning first to

\footnotetext{
${ }^{19}$ This estimate is obtained as follows: $\frac{\partial \text { verbal abuse }}{\partial \# \text { states }}=0.011+(0.005) x(O I L)=0.016$ if apprehended in a state with an OIL in place (i.e. OIL=1), or 0.011 otherwise.
} 
return intentions (Table 5), we find that English speaking migrants have higher intentions to cross again than migrants who do not speak the language. English speakers are likely more assimilated and, therefore, might have more to gain from crossing over on account of possessing U.S.-specific human capital. Those who crossed with a coyote are 4 percentage points less likely to expect to return within a week and 2 percentage points less likely to ever attempt another crossing than those who did not use such services. Given the steepness of coyote fees, cost considerations may explain these findings, particularly in the case of immediate return intentions. Finally, it is interesting that migrants with primary and tertiary education are less likely to report planning on ever crossing again relative to those with a secondary education -a finding consistent with the intermediate selection of immigrants from Mexico. ${ }^{20}$

To conclude, it is also worth noting how the incidence of mistreatment varies according to where apprehensions take place (see Table 6). For instance, with the exception of being uninformed about the right to counsel, all other migrant rights' violations are more likely to take place when apprehensions occurred at work (relative to elsewhere -the reference category). Similarly, various types of mistreatment -including physical abuse, separation from family members and misinformation about the right to contact the Mexican consulate, appear more prevalent during home apprehensions than during apprehensions elsewhere. Apprehensions at work and at home are less public, allowing for the escalation of a confrontation or for negligence during the detention procedure. In contrast, relative to those in the reference category, deportees apprehended on the street, while more likely to be uninformed about the right to counsel, do not experience a higher exposure to other types of mistreatment.

\footnotetext{
${ }^{20}$ Chiquiar and Hanson (2005), among others, find evidence of an intermediate selection of immigrants from Mexico with respect to the education distribution. The latter results from the fact that: (a) migration costs preclude those with low schooling from migrating, and (b) high returns to schooling in Mexico dissuade those with high schooling from migrating.
} 


\section{Summary and Conclusions}

In this study, we examine some of the intended and unintended consequences of increased border and interior immigration enforcement as captured by Operation Streamline and by Omnibus Immigration Laws. We first assess the effectiveness of federal and state-level initiatives in curtailing deportees' intent to return to the United States in the immediate and further future -an aim or intended consequence of these policies. Subsequently, we explore some unintended consequences of these policies - namely how they have impacted the treatment received by deportees during their detention. In the case of OS, we also look at how the policy may have induced migrants to risk their lives in order to cross over into the United States.

We find that apprehension in a Border Patrol sector with OS in place has no statistically significant impact on deportees' intent to return to the United States. In contrast, apprehension in a state with an OIL in place does lower migrants' immediate (within a week of deportation) return intentions by 7.6 percentage points, while stemming the intent to attempt a new crossing in the further future by 24 percentage points.

The scorecard of the federal and state policies with regard to migrants' rights violations and well-being is mixed. Apprehension in a Border Patrol sector with OS in place does not seem to increase the likelihood of mistreatment along many dimensions. In fact, there is evidence of declines in deportees' likelihood of being verbally abused and in their likelihood of being misinformed about the right to contact the Mexican Consulate as OS is progressively adopted by other Border Patrol sectors. However, the likelihood of risking one's life when crossing is significantly higher among deportees apprehended in an OS sector than among their counterparts detained in non-OS sectors. Furthermore, the progressive expansion of OS also seems to raise the likelihood of enduring life risks among those apprehended in sectors with OS in place, as 
well as the incidence of family separations among all deportees. These concerns have been reported in the press and our results seem to corroborate them.

There are significant costs associated with OILs as well. As in the case of OS, by 2012, apprehension in a state with an OIL in place was linked to a greater likelihood of being separated from family. Additionally, the incidence of physical and verbal abuse rises as the number of states implementing OILs increases. Perhaps, the growing number of state-level OILs is an expression of an evolving anti-immigrant sentiment propelled by a "herding" or "ganging-up" effect. This is an area worthy of further research. However, it is also interesting that there are some positives stemming from the implementation of state-level OILs with regard to migrant mistreatment. For instance, we observe a reduced incidence of misinformation about the right to contact the Mexican Consulate among those apprehended in a state with an OIL. Maybe increased awareness by law enforcement personnel of the importance of letting detainees know about their right to counsel has contributed to this outcome.

As noted, these findings are specific to the data available, which provides migrants' intentions to migrate as opposed to their actual behavior. Furthermore, we do not have information on all Mexicans but, rather, on deportees who have shown a predisposition for migrating to the United States illegally. Finally, we emphasize that our focus is on the overall impact of the policies, whether these impacts originate from their effects on the behavior of Border Patrol officers, interior enforcement personnel, deportees or on the type of prospective migrant.

Still, the results reveal that, while in some instances the policies are somewhat effective at reducing the intention to commit recidivism by deportees, recent immigration enforcement policies at the federal and state-level have substantially raised some human costs endured by 
migrants. Examples of such costs include a significant increase in the proportion of deportees who claim risking their lives to cross and an increased likelihood of being separated from family members during the deportation process. A full accounting of these human costs, alongside the limited effectiveness of these policies, should be taken into consideration when evaluating alternative programs. Doing so is imperative, especially considering the rise in mistreatment that we observe with the prevalence of the policies, raising important questions about their ultimate impacts if implemented throughout the country. 
Bibliography

Amuedo-Dorantes, C \& Bansak, C. (2012). U.S. border control: Counterpoint. In J. Gans, E.M. Replogle \& D.J. Tichenor (Eds.). Debates on U.S. Immigration (pp. 153-161). Thousand Oaks: SAGE Publication, Inc.

Amuedo-Dorantes, C. \& Lozano, F. (Forthcoming). On the Effectiveness of SB1070 in Arizona. Economic Inquiry.

Amuedo-Dorantes, C., Puttitanun T. \& Martinez-Donate, A. (2013). How do tougher immigration measures impact unauthorized immigrants? Demography, 50(3), 1067-1091.

Angelucci, M. (2012). U.S. border enforcement and the net flow of Mexican illegal migration. Economic Development and Cultural Change, 60(2), 311 - 357.

Bean, F D., Espenshade,T.J., White, M.J. \& Dymowksi, R. F. (1990). Post-IRCA changes in the volume and composition of undocumented migration to the United States: An assessment based on apprehension data. In F.D. Bean, B. Edmonston \& J.S. Passel (Eds.), Undocumented migration to the United States: IRCA and the experience of the 1980s (pp. 111-158). Washington, DC: Urban Institute.

Bohn, S., Lofstrom, M. \& Raphael, S. (2014). Did the 2007 Legal Arizona Workers Act reduce the state's unauthorized immigrant population? The Review of Economics and Statistics, 96(2), 258-269.

Bustamante, J. A. (1990). Measuring the flow of undocumented immigrants: Research findings from the Zapata Canyon Project. In F.D. Bean, B. Edmonston \& J.S. Passel (Eds.), Undocumented migration to the United States: IRCA and the experience of the 1980s (pp. 211226).Washington, DC: Urban Institute.

Cañas, J., Daly, C., \& Orrenius, P. (2012). Did Operation Streamline slow illegal immigration? Unpublished manuscript.

Chavez, L. R., Flores,E. T. \& Lopez-Garza, M. (1990). Here today, gone tomorrow? Undocumented settlers and immigration reform. Human Organization, 49(3),193-204.

Chiquiar, D. \& Hanson, G. H. (2005). International migration, self-selection, and the distribution of wages: Evidence from Mexico and the United States. Journal of Political Economy, 113(2), 239-281.

Cornelius, W. A. (1989). Impacts of the 1986 U.S. immigration law on emigration from rural Mexican sending communities. Population and Development Review, 15(4), 689-705.

Cornelius, W. A. (1998). The Structural Embeddedness of Demand for Mexican Immigrant Labor: New Evidence from California. In M. Suárez-Orozco (Ed.), Crossings: Mexican immigration in interdisciplinary perspective (pp. 114-144). Cambridge, MA: Harvard University Press/David Rockefeller Center for Latin American Studies. 
Dávila, A., Pagán, J.A. and Soydemir, G. (2002). The short-term and long-term deterrence effects of INS border and interior enforcement on undocumented immigration. Journal of Economic Behavior \& Organization, 49(4), 459-472.

Diaz, G. and Kuhner, G. (2007). Women migrants in transit and detention in Mexico. Washington DC: Migration Policy Institute.

Donato, K. M., Durand, J \& Massey, D. S. (1992). Stemming the tide? Assessing the deterrent effects of the Immigration Reform and Control Act.Demography, 29(2), 139-157.

Espenshade, T. J. (1990). Undocumented migration to the United States: Evidence from a repeated trials model, In F.D. Bean, B. Edmonston \& J.S. Passel (Eds.), Undocumented migration to the United States: IRCA and the experience of the 1980s (pp.158-182).Washington, DC: Urban Institute.

Espenshade, T. J. (1994). Does the threat of border apprehension deter undocumented U.S. immigration? Population and Development Review, 20(4), 871-92.

Fernández, V. (2011). Border patrol abuses on the rise. News report. New America Media. http://newamericamedia.org/2011/09/report-border-patrol-abuses-on-the-rise.php, accessed 3 July 2014.

Gonzalez de la Rocha, M. \& Escobar Latapi, A. (1990). The impact of IRCA on the migration patterns of a community in Los Altos, Jalisco, Mexico. Working Paper No. 41, Commission for the Study of International Migration and Cooperative Economic Development

Hanson, G. H. \& Spilimbergo, A. (1999). Illegal immigration, border enforcement, and relative wages: Evidence from apprehensions at the U.S.-Mexico Border. American Economic Review, 89(5), 1337-1357.

Immigration Policy Center. (2011). Checklist for estimating the costs of SB1070-style legislation. Washington DC: American Immigration Council. www.americanimmigrationcouncil.org/just-facts/checklist-estimating-costs-sb-1070-stylelegislation. Accessed 3 July 2014.

Kossoudji, S. A. (1992). Playing cat and mouse at the U.S.-Mexican border. Demography, 29(2), 159-180.

Lydgate, J. (2010). Assembly line justice: A review of Operation Streamline. Policy Brief. U. C. Berkeley: The Chief Justice Earl Warren Institute on Race, Ethnicity \& Diversity. https://www.law.berkeley.edu/files/Operation_Streamline_Policy_Brief.pdf. Accessed 3 July 2014.

Massey, D S., Donato, K.M. \& Liang, Z. (1990). Effects of the Immigration Reform and Control Act of 1986: Preliminary data from Mexico. In F.D. Bean, B. Edmonston \& J.S. Passel (Eds.), 
Undocumented migration to the United States: IRCA and the experience of the 1980s (pp. 182210).Washington, DC: Urban Institute.

Massey, D. S. and Riosmena, F. (2010). Undocumented migration from Latin America in an era of rising U.S. enforcement, The ANNALS of the American Academy of Political and Social Science, 630, 294-321.

Meissner, D., Kerwin, D. M., Chishti, M. \& Bergeron, C. (2013). Immigration enforcement in the United States: The rise of a formidable machinery. Report. Washington, DC: Migration Policy Institute. http://www.migrationpolicy.org/research/immigration-enforcement-unitedstates-rise-formidable-machinery. Accessed 3 July 2014.

Organization of American States. (2003). Special rapporteurship on migrant workers and their families 2003. Washington DC: Inter-American Commission on Human Rights. http://www.cidh.org/Migrantes/2003.eng.cap5c.htm. Accessed 3 July 2014.

Orrenius, P. M. (2001). Illegal immigration and enforcement along the U.S.-Mexico border: An overview. Economic and Financial Policy Review, Federal Reserve Bank of Dallas, First Quarter, 2001. https://www.dallasfed.org/assets/documents/research/efr/2001/efr0101a.pdf. Acessed 3 July 2014.

Orrenius, P. M., \& Zavodny, M. (2003). Do amnesty programs reduce undocumented immigration? Evidence from IRCA, Demography. 40(3), 437-450.

Ritcher, S. M., Taylor, J.E. \& Yunez-Naude, A. (2007). Impacts of policy reforms on labor migration from rural Mexico to the United States. In G. J. Borjas, (Ed.). Mexican immigration to the United States (pp. 269-288). Chicago: University of Chicago Press.

Rosenblum, M. R. (2012). Border security: Immigration enforcement between ports of entry. CRS Report for Congress. Washington DC: Congressional Research Service. http://fpc.state.gov/documents/organization/180681.pdf. Accessed 3 July 2014.

Singer, A. \& Massey, D. S. (1988). The social process of undocumented border crossing among Mexican migrants. International Migration Review, 32 (Fall), 561-592

Spener, D. (2001). Smuggling migrants through south Texas: Challenges posed by Operation Rio Grande. In D. Kyle \& T. Snyder, (Eds.), Global human smuggling: Comparative perspectives (pp. 129-165). Baltimore: John Hopkins University Press.

United Nations. (2002). Report of the Special Rapporteur on the human rights of migrants. Gabriela Rodríguez Pizarro, Submitted Pursuant To Commission On Human Rights Resolution 2002/62, U.N. Doc E/CN.4/2003/85. Geneva.

Varsanyi, M W. (Ed.) (2010). Taking local control: Immigration policy activism in U.S. cities and states. Stanford: Stanford University Press. 
White, M. J., Bean, F. D. \& Espenshade, T. J. (1990). The U.S. 1986 Immigration Reform and Control Act and undocumented migration to the United States. Population Research and Policy Review, 9(2), 93-116.

Wooldridge, J. M. (2008). Introductory Econometrics: A Modern Approach Ohio: SouthWestern Cengage Learning. 
Table 1

Descriptive Statistics

\begin{tabular}{|c|c|c|c|c|c|c|}
\hline \multirow{2}{*}{$\begin{array}{l}\text { Sample } \\
\text { Variables }\end{array}$} & \multicolumn{3}{|c|}{$\begin{array}{c}\text { Apprehended While } \\
\text { Crossing }\end{array}$} & \multicolumn{3}{|c|}{$\begin{array}{l}\text { Apprehended After Having } \\
\text { Successfully Crossed }\end{array}$} \\
\hline & $\mathbf{N}$ & Mean & S.D. & $\mathbf{N}$ & Mean & S.D. \\
\hline \multicolumn{7}{|l|}{ Independent Variables } \\
\hline Male & 33811 & 0.81 & 0.39 & 24109 & 0.86 & 0.35 \\
\hline Age & 33808 & 27.90 & 8.59 & 24105 & 29.74 & 8.89 \\
\hline Indigenous Language & 33799 & 0.10 & 0.30 & 24090 & 0.08 & 0.27 \\
\hline Speaks English & 33804 & 0.06 & 0.24 & 24096 & 0.26 & 0.44 \\
\hline No Education & 33805 & 0.03 & 0.18 & 24102 & 0.03 & 0.17 \\
\hline Primary Education & 33805 & 0.35 & 0.48 & 24102 & 0.33 & 0.47 \\
\hline Secondary Education & 33805 & 0.46 & 0.50 & 24102 & 0.44 & 0.50 \\
\hline Preparatoria & 33805 & 0.13 & 0.34 & 24102 & 0.15 & 0.36 \\
\hline Tertiary Education & 33805 & 0.02 & 0.13 & 24102 & 0.02 & 0.14 \\
\hline Married & 33804 & 0.56 & 0.50 & 24103 & 0.57 & 0.50 \\
\hline Household Head & 33807 & 0.49 & 0.50 & 24103 & 0.58 & 0.49 \\
\hline Family Size & 33783 & 4.98 & 2.04 & 24081 & 4.69 & 2.03 \\
\hline No. of Previous Crossings & 33676 & 0.51 & 1.77 & 23932 & 1.01 & 3.27 \\
\hline No. of Previous Deportations & 33689 & 0.21 & 1.02 & 24017 & 0.42 & 1.30 \\
\hline Crossed without Documents & 33769 & 0.74 & 0.44 & 24050 & 0.79 & 0.41 \\
\hline Crossed with a Coyote & 33777 & 0.64 & 0.48 & 23992 & 0.51 & 0.50 \\
\hline Duration of Last Migration Spell (Days) & 33779 & 53 & 475 & 24064 & 1186 & 2060 \\
\hline Apprehended while Crossing & 33779 & 1 & 1 & & & \\
\hline Detained in a Border Patrol sector with Operation Streamline & 33811 & 0.58 & 0.49 & & & \\
\hline No. of Border Patrol sectors implementing Operation Streamline & 33811 & 4.35 & 2.30 & & & \\
\hline Apprehended at Work & & & & 24109 & 0.10 & 0.30 \\
\hline Apprehended at Home & & & & 24109 & 0.09 & 0.29 \\
\hline Apprehended on the Street & & & & 24109 & 0.63 & 0.48 \\
\hline Apprehended on Another Location & & & & 24109 & 0.18 & 0.38 \\
\hline Detained in a State with an Omnibus Immigration Law & & & & 24109 & 0.09 & 0.29 \\
\hline Number of States with an Omnibus Immigration Law & & & & 24109 & 0.79 & 1.94 \\
\hline \multicolumn{7}{|l|}{ Dependent Variables } \\
\hline Intent to Return Next Week & 33662 & 0.74 & 0.44 & 23984 & 0.64 & 0.48 \\
\hline Intent to Return Ever & 33479 & 0.88 & 0.33 & 23910 & 0.86 & 0.35 \\
\hline Sustained Physical Abuse & 33784 & 0.04 & 0.20 & 24085 & 0.05 & 0.21 \\
\hline Sustained Verbal Abuse & 33811 & 0.11 & 0.31 & 24109 & 0.12 & 0.32 \\
\hline Belongings Were Confiscated & 33784 & 0.03 & 0.18 & 24084 & 0.05 & 0.22 \\
\hline Separated from Family Members at Deportation & 14603 & 0.24 & 0.43 & 13423 & 0.59 & 0.49 \\
\hline Uninformed about Right to Contact the Consulate & 33801 & 0.84 & 0.37 & 24102 & 0.70 & 0.46 \\
\hline Risked Life to Cross & 33780 & 0.21 & 0.41 & 23984 & 0.64 & 0.48 \\
\hline
\end{tabular}

Data: 2005-2012 waves of the deported sample of the EMIF-Norte. 
Table 2A

Share of Deported Immigrants Apprehended While Crossing Reporting Any of the Following:

\begin{tabular}{|c|c|c|c|c|c|c|c|c|}
\hline By Year & 2005 & 2006 & 2007 & 2008 & 2009 & 2010 & 2011 & 2012 \\
\hline \multicolumn{9}{|c|}{ Apprehended in States Border Patrol Sectors without Operation Streamline } \\
\hline \multicolumn{9}{|l|}{ Intent to Return to the United States: } \\
\hline Next Week & 0.70 & 0.76 & 0.88 & 0.75 & 0.73 & 0.62 & 0.51 & 0.33 \\
\hline Ever & 0.92 & 0.92 & 0.96 & 0.92 & 0.84 & 0.80 & 0.79 & 0.78 \\
\hline \multicolumn{9}{|l|}{ Type of Mistreatment: } \\
\hline Sustained Physical Abuse & 0.07 & 0.06 & 0.04 & 0.04 & 0.06 & 0.05 & 0.03 & 0.02 \\
\hline Sustained Verbal Abuse & 0.15 & 0.17 & 0.12 & 0.14 & 0.10 & 0.11 & 0.09 & 0.12 \\
\hline Belongings Were Confiscated & 0.03 & 0.02 & 0.01 & 0.03 & 0.04 & 0.05 & 0.07 & 0.08 \\
\hline Separated from Family Members at Deportation & 0.24 & 0.15 & 0.11 & 0.18 & 0.32 & 0.64 & 0.70 & 0.80 \\
\hline Uninformed about Right to Contact the Consulate & 0.86 & 0.86 & 0.91 & 0.86 & 0.85 & 0.68 & 0.49 & 0.41 \\
\hline \multicolumn{9}{|l|}{ Crossing Difficulties: } \\
\hline Risked Life to Cross & 0.33 & 0.28 & 0.26 & 0.21 & 0.11 & 0.16 & 0.20 & 0.32 \\
\hline \multicolumn{9}{|c|}{ Apprehended in Border Patrol Sectors with Operation Streamline } \\
\hline \multicolumn{9}{|l|}{ Intent to Return to the United States: } \\
\hline Next Week & - & 0.52 & 0.30 & 0.84 & 0.80 & 0.78 & 0.44 & 0.26 \\
\hline Ever & - & 0.87 & 0.66 & 0.93 & 0.87 & 0.87 & 0.76 & 0.71 \\
\hline \multicolumn{9}{|l|}{ Type of Mistreatment: } \\
\hline Sustained Physical Abuse & - & 0.03 & 0.07 & 0.05 & 0.03 & 0.03 & 0.02 & 0.03 \\
\hline Sustained Verbal Abuse & - & 0.03 & 0.10 & 0.12 & 0.10 & 0.09 & 0.07 & 0.13 \\
\hline Belongings Were Confiscated & - & 0.04 & 0.01 & 0.04 & 0.03 & 0.01 & 0.05 & 0.14 \\
\hline Separated from Family Members at Deportation & - & 0.47 & 0.55 & 0.14 & 0.20 & 0.18 & 0.43 & 0.54 \\
\hline Uninformed about Right to Contact the Consulate & - & 0.77 & 0.68 & 0.91 & 0.92 & 0.89 & 0.60 & 0.34 \\
\hline \multicolumn{9}{|l|}{ Crossing Difficulties: } \\
\hline Risked Life to Cross & - & 0.14 & 0.22 & 0.27 & 0.27 & 0.10 & 0.11 & 0.12 \\
\hline
\end{tabular}

Data: 2005-2012 waves of the deported sample of the EMIF-Norte. 
Table 2B

Share of Deported Immigrants Apprehended in the Interior Reporting Any of the Following:

By Year 2005

2006

2007

2008

2009

2010

2011

Apprehended in States without Omnibus Immigration Laws

Intent to Return to the United States:

Next Week

Ever

\subsection{5}

0.82

0.76

0.59

0.55

0.49

0.40

0.21

Type of Mistreatment:

Sustained Physical Abuse

Sustained Verbal Abuse

Belongings Were Confiscated

Separated from Family Members at Deportation

Uninformed about Right to Contact the Consulate

$0.96 \quad 0.94$

0.92

0.87

0.77

0.78

0.76

0.76

\section{Crossing Difficulties:}

Risked Life to Cross

$0.03 \quad 0.06$

$\begin{array}{ll}0.03 & 0.06 \\ 0.09 & 0.18\end{array}$

$\begin{array}{ll}0.09 & 0.18 \\ 0.02 & 0.01\end{array}$

$0.14 \quad 0.21$

$\begin{array}{ll}0.88 & 0.89\end{array}$

$\begin{array}{ll}0.05 & 0.06 \\ 0.14 & 0.14 \\ 0.01 & 0.06 \\ 0.31 & 0.64 \\ 0.82 & 0.70\end{array}$

0.05

0.11

0.11
0.07

0.06

0.10

0.09

$0.71 \quad 0.78$

$\begin{array}{ll}0.59 & 0.55\end{array}$

0.05

0.09

0.10

0.92

0.43

0.04

0.10

0.16

0.16
0.85

0.29

\begin{tabular}{lllll} 
& 0.27 & 0.30 & 0.37 & 0.23 \\
\hline & Apprehended in States with Omnibus Immigration Laws
\end{tabular}

Intent to Return to the United States:

Next Week

Ever

\section{Type of Mistreatment:}

Sustained Physical Abuse

Sustained Verbal Abuse

Belongings Were Confiscated

Separated from Family Members at Deportation

Uninformed about Right to Contact the Consulate

Crossing Difficulties:

Risked Life to Cross

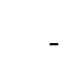

$-$

0.18

0.19

0.17

Data: 2005-2012 waves of the deported sample of the EMIF-Norte. 
Table 3

Linear Probability Model Estimates of the Intent of Recidivism of Deportees Apprehended While Crossing

\begin{tabular}{|c|c|c|}
\hline Outcome & Intent to Return Next Week & Intent to Ever Return \\
\hline Detained in a BP Sector with OS & $\begin{array}{c}0.024 \\
(0.048)\end{array}$ & $\begin{array}{l}-0.012 \\
(0.032)\end{array}$ \\
\hline No. of BP Sectors with OS & $\begin{array}{l}-0.028 \\
(0.031)\end{array}$ & $\begin{array}{c}0.006 \\
(0.015)\end{array}$ \\
\hline OS BP Sector*No. of BP Sectors with OS & $\begin{array}{l}-0.007 \\
(0.006)\end{array}$ & $\begin{array}{l}-0.008 * \\
(0.004)\end{array}$ \\
\hline Male & $\begin{array}{l}0.054 * \\
(0.016)\end{array}$ & $\begin{array}{c}0.060 * * \\
(0.014)\end{array}$ \\
\hline Age & $\begin{array}{l}-0.001 \\
(0.001)\end{array}$ & $\begin{array}{c}-0.001 * * \\
(1.71 \mathrm{e}-04)\end{array}$ \\
\hline Indigenous Language & $\begin{array}{l}-0.003 \\
(0.024)\end{array}$ & $\begin{array}{c}0.003 \\
(0.011)\end{array}$ \\
\hline Speaks English & $\begin{array}{l}-0.002 \\
(0.025)\end{array}$ & $\begin{array}{l}-0.006 \\
(0.015)\end{array}$ \\
\hline Primary Education & $\begin{array}{l}-0.003 \\
(0.012)\end{array}$ & $\begin{array}{c}0.005 \\
(0.012)\end{array}$ \\
\hline Secondary Education & $\begin{array}{c}-9.53 e-06 \\
(0.007)\end{array}$ & $\begin{array}{c}0.001 \\
(0.013)\end{array}$ \\
\hline Preparatoria & $\begin{array}{c}0.016 \\
(0.018)\end{array}$ & $\begin{array}{c}0.008 \\
(0.009)\end{array}$ \\
\hline Tertiary Education & $\begin{array}{c}0.038 \\
(0.046)\end{array}$ & $\begin{array}{l}-0.001 \\
(0.023)\end{array}$ \\
\hline Married & $\begin{array}{c}0.006 \\
(0.010)\end{array}$ & $\begin{array}{l}-0.004 \\
(0.008)\end{array}$ \\
\hline Household Head & $\begin{array}{l}-0.010 \\
(0.016)\end{array}$ & $\begin{array}{c}3.87 \mathrm{e}-04 \\
(0.006)\end{array}$ \\
\hline Family Size & $\begin{array}{c}0.003 \\
(0.002)\end{array}$ & $\begin{array}{c}0.001 \\
(0.001)\end{array}$ \\
\hline No. of Previous Crossings & $\begin{array}{c}0.002 \\
(0.003)\end{array}$ & $\begin{array}{l}0.006 \dagger \\
(0.003)\end{array}$ \\
\hline No. of Previous Deportations & $\begin{array}{c}-0.027 * * \\
(0.007)\end{array}$ & $\begin{array}{c}-0.010 * * \\
(0.003)\end{array}$ \\
\hline Crossed without documents & $\begin{array}{c}0.002 \\
(0.031)\end{array}$ & $\begin{array}{c}0.079 * * \\
(0.011)\end{array}$ \\
\hline Crossed with a coyote & $\begin{array}{l}-0.001 \\
(0.059)\end{array}$ & $\begin{array}{c}0.026 \\
(0.016)\end{array}$ \\
\hline Duration of Last Spell (in Days) & $\begin{array}{c}1.42 \mathrm{e}-05 \\
(7.72 \mathrm{e}-06)\end{array}$ & $\begin{array}{c}5.80 \mathrm{e}-06 \\
(8.47 \mathrm{e}-06)\end{array}$ \\
\hline Observations & 32,392 & 32,213 \\
\hline R-squared & 0.192 & 0.113 \\
\hline
\end{tabular}

Note: Regressions contain a constant as well as BP sector FE, time FE and a BP sector-time trend. S.E. (in parentheses) clustered at BP sector level. ** $\mathrm{p}<0.01, * \mathrm{p}<0.05, \dagger \mathrm{p}<0.10$

Data: 2005-2012 waves of the deported sample of the EMIF-Norte. 
Table 4: Linear Probability Model Estimates of Self-reported Mistreatment by Deportees Apprehended While Crossing

\begin{tabular}{|c|c|c|c|c|c|c|}
\hline Outcome & $\begin{array}{l}\text { Physical } \\
\text { Abuse }\end{array}$ & $\begin{array}{l}\text { Verbal } \\
\text { Abuse }\end{array}$ & $\begin{array}{c}\text { Property } \\
\text { Confiscated }\end{array}$ & $\begin{array}{c}\text { Separated } \\
\text { from Family }\end{array}$ & $\begin{array}{l}\text { Uninformed About } \\
\text { Right to Consul }\end{array}$ & $\begin{array}{l}\text { Risked Their } \\
\text { Lives to Cross }\end{array}$ \\
\hline Detained in a BP Sector with OS & $\begin{array}{l}-0.005 \\
(0.049)\end{array}$ & $\begin{array}{c}0.004 \\
(0.055)\end{array}$ & $\begin{array}{c}0.007 \\
(0.037)\end{array}$ & $\begin{array}{l}-0.008 \\
(0.047)\end{array}$ & $\begin{array}{l}-0.013 \\
(0.048)\end{array}$ & $\begin{array}{c}0.002 \\
(0.013)\end{array}$ \\
\hline No. of BP Sectors with OS & $\begin{array}{l}-0.012 \\
(0.014)\end{array}$ & $\begin{array}{c}-0.034 * \\
(0.014)\end{array}$ & $\begin{array}{l}-0.012 \\
(0.012)\end{array}$ & $\begin{array}{l}0.091 \dagger \\
(0.042)\end{array}$ & $\begin{array}{c}-0.054^{*} \\
(0.018)\end{array}$ & $\begin{array}{c}0.004 \\
(0.014)\end{array}$ \\
\hline OS BP Sector*No. of BP Sectors with OS & $\begin{array}{l}-0.001 \\
(0.005)\end{array}$ & $\begin{array}{l}-0.001 \\
(0.005)\end{array}$ & $\begin{array}{c}0.005 \\
(0.005)\end{array}$ & $\begin{array}{l}-0.003 \\
(0.006)\end{array}$ & $\begin{array}{c}0.004 \\
(0.007)\end{array}$ & $\begin{array}{c}0.020 * * \\
(0.004)\end{array}$ \\
\hline Male & $\begin{array}{c}0.027 \\
(0.019)\end{array}$ & $\begin{array}{c}0.014 \\
(0.021)\end{array}$ & $\begin{array}{c}0.002 \\
(0.008)\end{array}$ & $\begin{array}{c}0.063 \\
(0.045)\end{array}$ & $\begin{array}{l}-0.020 \\
(0.015)\end{array}$ & $\begin{array}{l}-0.037 \\
(0.027)\end{array}$ \\
\hline Age & $\begin{array}{c}0.001 \\
(4.24 \mathrm{e}-04)\end{array}$ & $\begin{array}{l}0.002 \dagger \\
(0.001)\end{array}$ & $\begin{array}{c}0.001 \\
(4.00 \mathrm{e}-04)\end{array}$ & $\begin{array}{c}0.004 * * \\
(0.001)\end{array}$ & $\begin{array}{l}-3.11 \mathrm{e}-04 \\
(0.001)\end{array}$ & $\begin{array}{c}0.002 \\
(0.002)\end{array}$ \\
\hline Indigenous Language & $\begin{array}{c}0.015 \\
(0.016)\end{array}$ & $\begin{array}{c}0.018 \\
(0.027)\end{array}$ & $\begin{array}{c}0.018 \\
(0.011)\end{array}$ & $\begin{array}{c}0.002 \\
(0.031)\end{array}$ & $\begin{array}{l}-0.024 \\
(0.014)\end{array}$ & $\begin{array}{c}0.034 \\
(0.021)\end{array}$ \\
\hline Speaks English & $\begin{array}{l}-0.002 \\
(0.030)\end{array}$ & $\begin{array}{c}0.006 \\
(0.035)\end{array}$ & $\begin{array}{c}0.020 \\
(0.026)\end{array}$ & $\begin{array}{l}0.148^{*} \\
(0.062)\end{array}$ & $\begin{array}{l}-0.009 \\
(0.025)\end{array}$ & $\begin{array}{c}0.016 \\
(0.025)\end{array}$ \\
\hline Primary Education & $\begin{array}{c}0.006 \\
(0.008)\end{array}$ & $\begin{array}{c}0.017 \\
(0.014)\end{array}$ & $\begin{array}{c}0.002 \\
(0.005)\end{array}$ & $\begin{array}{c}0.030 \\
(0.028)\end{array}$ & $\begin{array}{c}0.004 \\
(0.015)\end{array}$ & $\begin{array}{c}0.018 \\
(0.023)\end{array}$ \\
\hline Secondary Education & $\begin{array}{l}0.024 \dagger \\
(0.012)\end{array}$ & $\begin{array}{l}0.052 * \\
(0.015)\end{array}$ & $\begin{array}{l}0.018 * \\
(0.006)\end{array}$ & $\begin{array}{c}-0.011 \\
(0.028)\end{array}$ & $\begin{array}{c}-0.013 \\
(0.018)\end{array}$ & $\begin{array}{c}0.056 \\
(0.039)\end{array}$ \\
\hline Preparatoria & $\begin{array}{c}0.059 \\
(0.032)\end{array}$ & $\begin{array}{c}0.104 * * \\
(0.028)\end{array}$ & $\begin{array}{c}0.031 \\
(0.021)\end{array}$ & $\begin{array}{l}-0.024 \\
(0.033)\end{array}$ & $\begin{array}{c}-0.034 \\
(0.032)\end{array}$ & $\begin{array}{c}0.027 \\
(0.045)\end{array}$ \\
\hline Tertiary Education & $\begin{array}{l}0.034 \dagger \\
(0.015)\end{array}$ & $\begin{array}{l}0.028 * \\
(0.012)\end{array}$ & $\begin{array}{c}0.010 \\
(0.006)\end{array}$ & $\begin{array}{c}0.037 \\
(0.048)\end{array}$ & $\begin{array}{c}0.000 \\
(0.025)\end{array}$ & $\begin{array}{c}0.043 \\
(0.043)\end{array}$ \\
\hline Married & $\begin{array}{c}0.002 \\
(0.010)\end{array}$ & $\begin{array}{l}-0.009 \\
(0.010)\end{array}$ & $\begin{array}{c}-4.84 \mathrm{e}-04 \\
(0.008)\end{array}$ & $\begin{array}{c}-0.049 * * \\
(0.008)\end{array}$ & $\begin{array}{l}-0.013 \\
(0.025)\end{array}$ & $\begin{array}{c}-0.006 \\
(0.012)\end{array}$ \\
\hline Household Head & $\begin{array}{l}-0.010 \\
(0.014)\end{array}$ & $\begin{array}{c}0.002 \\
(0.016)\end{array}$ & $\begin{array}{l}-0.005 \\
(0.009)\end{array}$ & $\begin{array}{c}0.009 \\
(0.022)\end{array}$ & $\begin{array}{c}0.013 \\
(0.026)\end{array}$ & $\begin{array}{c}-0.019 * \\
(0.008)\end{array}$ \\
\hline Family Size & $\begin{array}{l}-0.004 \\
(0.004)\end{array}$ & $\begin{array}{l}-0.004 \\
(0.005)\end{array}$ & $\begin{array}{c}-0.002 \\
(0.002)\end{array}$ & $\begin{array}{c}-0.009 * \\
(0.004)\end{array}$ & $\begin{array}{l}0.005 \dagger \\
(0.002)\end{array}$ & $\begin{array}{c}0.003 \\
(0.004)\end{array}$ \\
\hline No. of Previous Crossings & $\begin{array}{c}-0.001 \\
(0.003)\end{array}$ & $\begin{array}{c}-0.005 \\
(0.006)\end{array}$ & $\begin{array}{c}-0.005^{* *} \\
(0.001)\end{array}$ & $\begin{array}{c}-0.001 \\
(0.002)\end{array}$ & $\begin{array}{c}-0.006 \\
(0.006)\end{array}$ & $\begin{array}{c}-0.008 \dagger \\
(0.004)\end{array}$ \\
\hline
\end{tabular}


Table 4 - Cont'd

\begin{tabular}{lcccccc} 
Outcome & $\begin{array}{c}\text { Physical } \\
\text { Abuse }\end{array}$ & $\begin{array}{c}\text { Verbal } \\
\text { Abuse }\end{array}$ & $\begin{array}{c}\text { Property } \\
\text { Confiscated }\end{array}$ & $\begin{array}{c}\text { Separated } \\
\text { from Family }\end{array}$ & $\begin{array}{c}\text { Uninformed About } \\
\text { Right to Consul }\end{array}$ & $\begin{array}{c}\text { Risked Their } \\
\text { Lives to Cross }\end{array}$ \\
No. of Previous Deportations & -0.001 & 0.008 & $0.014^{*}$ & $0.021^{* *}$ & -0.008 & 0.013 \\
& $(0.006)$ & $(0.008)$ & $(0.004)$ & $(0.006)$ & $(0.006)$ & $(0.008)$ \\
Crossed without documents & -0.003 & 0.006 & 0.013 & 0.076 & $-0.065^{*}$ & 0.038 \\
& $(0.022)$ & $(0.028)$ & $(0.018)$ & $(0.051)$ & $(0.019)$ & $(0.041)$ \\
Crossed with a coyote & 0.011 & 0.048 & 0.001 & -0.002 & -0.027 & $0.071^{*}$ \\
& $(0.023)$ & $(0.058)$ & $(0.012)$ & $(0.017)$ & $(0.039)$ & $(0.022)$ \\
Duration of Last Spell (in Days) & $-1.57 \mathrm{e}-06$ & $-1.10 \mathrm{e}-05^{*}$ & $1.16 \mathrm{e}-06$ & $6.54 \mathrm{e}-06^{* *}$ & $1.96 \mathrm{e}-06$ & $-1.42 \mathrm{e}-05$ \\
& $(1.94 \mathrm{e}-06)$ & $(3.44 \mathrm{e}-06)$ & $(3.65 \mathrm{e}-06)$ & $(1.05 \mathrm{e}-05)$ & $(5.40 \mathrm{e}-06)$ & $(7.98 \mathrm{e}-06)$ \\
Observations & 32,493 & 32,517 & 32,493 & 14,014 & 32,512 & 32,495 \\
R-squared & 0.120 & 0.097 & 0.080 & 0.244 & 0.255 \\
\hline
\end{tabular}

Notes: Regressions contain a constant as well as BP sector FE, time FE and a BP sector-time trend. S.E. (in parentheses) clustered at BP sector level. $* * \mathrm{p}<0.01, * \mathrm{p}<0.05, \dagger \mathrm{p}<0.10$.

Data: 2005-2012 waves of the deported sample of the EMIF-Norte. 
Table 5

Linear Probability Model Estimates of the Intent of Recidivism of Deportees Apprehended in the Interior

\begin{tabular}{|c|c|c|}
\hline Outcome & Intent to Return Next Week & Intent to Ever Return \\
\hline Detained in a State with an OIL & $\begin{array}{c}-0.042 \\
(0.033)\end{array}$ & $\begin{array}{c}-0.022 \\
(0.023)\end{array}$ \\
\hline No. of States with OIL & $\begin{array}{c}-0.015 \\
(0.021)\end{array}$ & $\begin{array}{c}0.007 \\
(0.005)\end{array}$ \\
\hline OIL State*No. of States with OIL & $\begin{array}{c}-0.033 * * \\
(0.009)\end{array}$ & $\begin{array}{r}-0.009 \dagger \\
(0.004)\end{array}$ \\
\hline Apprehended at Work & $\begin{array}{c}0.014 \\
(0.029)\end{array}$ & $\begin{array}{l}0.032 \dagger \\
(0.017)\end{array}$ \\
\hline Apprehended at Home & $\begin{array}{l}-0.030 \\
(0.031)\end{array}$ & $\begin{array}{c}-0.001 \\
(0.016)\end{array}$ \\
\hline Apprehended on the Street & $\begin{array}{c}0.039 \\
(0.024)\end{array}$ & $\begin{array}{l}0.032 * \\
(0.014)\end{array}$ \\
\hline Male & $\begin{array}{l}0.057 \dagger \\
(0.029)\end{array}$ & $\begin{array}{l}0.073 * \\
(0.028)\end{array}$ \\
\hline Age & $\begin{array}{c}-9.44 \mathrm{e}-05 \\
(0.001)\end{array}$ & $\begin{array}{c}-0.001 * * \\
(2.66 \mathrm{e}-04)\end{array}$ \\
\hline Indigenous Language & $\begin{array}{l}-0.047 \\
(0.039)\end{array}$ & $\begin{array}{c}-0.022 \\
(0.023)\end{array}$ \\
\hline Speaks English & $\begin{array}{l}-0.009 \\
(0.015)\end{array}$ & $\begin{array}{c}0.039 * * \\
(0.012)\end{array}$ \\
\hline Primary Education & $\begin{array}{c}-0.041 * \\
(0.015)\end{array}$ & $\begin{array}{c}-0.022 \dagger \\
(0.012)\end{array}$ \\
\hline Secondary Education & $\begin{array}{l}-0.001 \\
(0.007)\end{array}$ & $\begin{array}{c}0.008 \\
(0.010)\end{array}$ \\
\hline Preparatoria & $\begin{array}{c}-0.002 \\
(0.009)\end{array}$ & $\begin{array}{c}0.006 \\
(0.008)\end{array}$ \\
\hline Tertiary Education & $\begin{array}{c}0.005 \\
(0.040)\end{array}$ & $\begin{array}{c}-0.039 * * \\
(0.014)\end{array}$ \\
\hline Married & $\begin{array}{l}0.019 \dagger \\
(0.011)\end{array}$ & $\begin{array}{c}0.009 \\
(0.009)\end{array}$ \\
\hline Household Head & $\begin{array}{l}-0.002 \\
(0.008)\end{array}$ & $\begin{array}{c}-0.013 \\
(0.021)\end{array}$ \\
\hline Family Size & $\begin{array}{c}0.006 \\
(0.004)\end{array}$ & $\begin{array}{c}-3.04 \mathrm{e}-04 \\
(0.002)\end{array}$ \\
\hline No. of Previous Crossings & $\begin{array}{c}0.002 \\
(0.002)\end{array}$ & $\begin{array}{c}0.001 \\
(0.002)\end{array}$ \\
\hline No. of Previous Deportations & $\begin{array}{c}-0.006 \\
(0.005)\end{array}$ & $\begin{array}{c}0.005 \\
(0.004)\end{array}$ \\
\hline Crossed without documents & $\begin{array}{l}0.037 * \\
(0.015)\end{array}$ & $\begin{array}{c}0.071 * * \\
(0.020)\end{array}$ \\
\hline Crossed with a coyote & $\begin{array}{c}-0.039 * \\
(0.015)\end{array}$ & $\begin{array}{c}-0.020 * \\
(0.008)\end{array}$ \\
\hline Duration of Last Spell (in Days) & $\begin{array}{l}-4.28 \mathrm{e}-06 \\
(3.59 \mathrm{e}-06)\end{array}$ & $\begin{array}{l}9.46 \mathrm{e}-06 * \\
(3.67 \mathrm{e}-06)\end{array}$ \\
\hline Observations & 23,561 & 23,488 \\
\hline R-squared & 0.224 & 0.119 \\
\hline
\end{tabular}

Note: Regressions contain a constant as well as state FE, time FE and a state-time trend. S.E. (in parentheses) clustered at state level. $* * \mathrm{p}<0.01, * \mathrm{p}<0.05, \dagger \mathrm{p}<0.1$.

Data: 2005-2012 waves of the deported sample of the EMIF-Norte. 
Table 6: Linear Probability Model Estimates of Self-reported Mistreatment by Deportees Apprehended in the Interior

\begin{tabular}{|c|c|c|c|c|c|}
\hline Outcome & $\begin{array}{l}\text { Physical } \\
\text { Abuse }\end{array}$ & $\begin{array}{l}\text { Verbal } \\
\text { Abuse }\end{array}$ & $\begin{array}{c}\text { Property } \\
\text { Confiscated }\end{array}$ & $\begin{array}{c}\text { Separated from } \\
\text { Family }\end{array}$ & $\begin{array}{l}\text { Uninformed About } \\
\text { Right to Consul }\end{array}$ \\
\hline Detained in an OIL state & $\begin{array}{c}-0.046 * * \\
(0.012)\end{array}$ & $\begin{array}{l}-0.113 * \\
(0.049)\end{array}$ & $\begin{array}{c}0.010 \\
(0.026)\end{array}$ & $\begin{array}{l}0.183 * * \\
(0.063)\end{array}$ & $\begin{array}{c}-0.116 * * \\
(0.027)\end{array}$ \\
\hline No. of states with OIL & $\begin{array}{l}-0.006 \\
(0.010)\end{array}$ & $\begin{array}{l}0.011 \dagger \\
(0.006)\end{array}$ & $\begin{array}{l}1.66 \mathrm{e}-04 \\
(0.007)\end{array}$ & $\begin{array}{c}0.028 * * \\
(0.005)\end{array}$ & $\begin{array}{c}-0.022 * * \\
(0.004)\end{array}$ \\
\hline OIL State $*$ No. of states with OIL & $\begin{array}{l}0.008 * \\
(0.003)\end{array}$ & $\begin{array}{c}0.005 \\
(0.004)\end{array}$ & $\begin{array}{c}0.001 \\
(0.006)\end{array}$ & $\begin{array}{c}-0.027 * * \\
(0.003)\end{array}$ & $\begin{array}{c}-0.026^{* *} \\
(0.002)\end{array}$ \\
\hline Apprehended at Work & $\begin{array}{l}0.104 * * \\
(0.004)\end{array}$ & $\begin{array}{l}0.163 * * \\
(0.036)\end{array}$ & $\begin{array}{l}0.119 * * \\
(0.041)\end{array}$ & $\begin{array}{l}0.280 * * \\
(0.059)\end{array}$ & $\begin{array}{l}-0.014 \\
(0.028)\end{array}$ \\
\hline Apprehended at Home & $\begin{array}{l}0.028 * \\
(0.013)\end{array}$ & $\begin{array}{c}0.053 \\
(0.044)\end{array}$ & $\begin{array}{c}0.004 \\
(0.003)\end{array}$ & $\begin{array}{c}0.155^{* *} \\
(0.019)\end{array}$ & $\begin{array}{l}0.054 * \\
(0.024)\end{array}$ \\
\hline Apprehended on the Street & $\begin{array}{c}0.017 \\
(0.015)\end{array}$ & $\begin{array}{c}0.078 \\
(0.049)\end{array}$ & $\begin{array}{l}-0.001 \\
(0.008)\end{array}$ & $\begin{array}{c}0.020 \\
(0.038)\end{array}$ & $\begin{array}{l}0.063 * * \\
(0.021)\end{array}$ \\
\hline Male & $\begin{array}{c}0.022 * * \\
(0.007)\end{array}$ & $\begin{array}{l}-0.012 \\
(0.013)\end{array}$ & $\begin{array}{c}0.004 \\
(0.003)\end{array}$ & $\begin{array}{l}0.052 * \\
(0.020)\end{array}$ & $\begin{array}{l}-0.007 \\
(0.014)\end{array}$ \\
\hline Age & $\begin{array}{c}3.73 \mathrm{e}-05 \\
(2.87 \mathrm{e}-04)\end{array}$ & $\begin{array}{c}0.001 \\
(0.001)\end{array}$ & $\begin{array}{l}3.24 \mathrm{e}-04 * \\
(1.39 \mathrm{e}-04)\end{array}$ & $\begin{array}{c}0.004 * * \\
(0.001)\end{array}$ & $\begin{array}{c}4.54 \mathrm{e}-04 \\
(0.001)\end{array}$ \\
\hline Indigenous Language & $\begin{array}{c}0.003 \\
(0.013)\end{array}$ & $\begin{array}{c}0.004 \\
(0.011)\end{array}$ & $\begin{array}{l}-0.016 \\
(0.010)\end{array}$ & $\begin{array}{l}0.033 \dagger \\
(0.020)\end{array}$ & $\begin{array}{l}-0.007 \\
(0.022)\end{array}$ \\
\hline Speaks English & $\begin{array}{c}-0.021 \\
(0.020)\end{array}$ & $\begin{array}{c}-0.007 \\
(0.011)\end{array}$ & $\begin{array}{c}-0.008 \\
(0.006)\end{array}$ & $\begin{array}{c}0.121 * * \\
(0.021)\end{array}$ & $\begin{array}{l}-0.021 * \\
(0.008)\end{array}$ \\
\hline Primary Education & $\begin{array}{c}-0.015 \dagger \\
(0.008)\end{array}$ & $\begin{array}{c}-0.017 * \\
(0.007)\end{array}$ & $\begin{array}{l}-0.012 \\
(0.010)\end{array}$ & $\begin{array}{c}0.026 \\
(0.028)\end{array}$ & $\begin{array}{l}-0.020 \\
(0.015)\end{array}$ \\
\hline Secondary Education & $\begin{array}{c}0.024 \\
(0.015)\end{array}$ & $\begin{array}{l}0.032 * \\
(0.015)\end{array}$ & $\begin{array}{c}0.001 \\
(0.009)\end{array}$ & $\begin{array}{c}0.002 \\
(0.036)\end{array}$ & $\begin{array}{c}-0.032 \\
(0.025)\end{array}$ \\
\hline Preparatoria & $\begin{array}{l}0.024 * \\
(0.011)\end{array}$ & $\begin{array}{c}0.058 * * \\
(0.018)\end{array}$ & $\begin{array}{c}0.027 * * \\
(0.010)\end{array}$ & $\begin{array}{c}0.016 \\
(0.039)\end{array}$ & $\begin{array}{c}-0.027 \\
(0.028)\end{array}$ \\
\hline Tertiary Education & $\begin{array}{c}0.039 * * \\
(0.009)\end{array}$ & $\begin{array}{c}0.022 \\
(0.042)\end{array}$ & $\begin{array}{c}0.008 \\
(0.020)\end{array}$ & $\begin{array}{l}0.075 \dagger \\
(0.041)\end{array}$ & $\begin{array}{c}-0.031 \\
(0.027)\end{array}$ \\
\hline Married & $\begin{array}{c}-0.003 \\
(0.004)\end{array}$ & $\begin{array}{c}-0.013 * * \\
(0.003)\end{array}$ & $\begin{array}{c}-0.013 * \\
(0.005)\end{array}$ & $\begin{array}{c}-0.042 \dagger \\
(0.021)\end{array}$ & $\begin{array}{c}1.71 \mathrm{e}-04 \\
(0.011)\end{array}$ \\
\hline
\end{tabular}


Table 6 - Cont'd

\begin{tabular}{|c|c|c|c|c|c|}
\hline Outcome & $\begin{array}{l}\text { Physical } \\
\text { Abuse }\end{array}$ & $\begin{array}{l}\text { Verbal } \\
\text { Abuse }\end{array}$ & $\begin{array}{l}\text { Property } \\
\text { Confiscated }\end{array}$ & $\begin{array}{c}\text { Separated from } \\
\text { Family }\end{array}$ & $\begin{array}{l}\text { Uninformed } \\
\text { About Right to } \\
\text { Consul }\end{array}$ \\
\hline Household Head & $\begin{array}{l}-0.011^{*} \\
(0.005)\end{array}$ & $\begin{array}{l}-0.005 \\
(0.010)\end{array}$ & $\begin{array}{c}-1.95 \mathrm{e}-05 \\
(0.004)\end{array}$ & $\begin{array}{c}0.001 \\
(0.026)\end{array}$ & $\begin{array}{l}-0.031 \\
(0.019)\end{array}$ \\
\hline Family Size & $\begin{array}{c}-0.002 \\
(0.002)\end{array}$ & $\begin{array}{c}0.001 \\
(0.003)\end{array}$ & $\begin{array}{l}-0.002 * \\
(0.001)\end{array}$ & $\begin{array}{c}-0.013 * * \\
(0.003)\end{array}$ & $\begin{array}{l}-0.002 \\
(0.004)\end{array}$ \\
\hline No. of Previous Crossings & $\begin{array}{l}0.001 \dagger \\
(0.000)\end{array}$ & $\begin{array}{c}8.15 \mathrm{e}-06 \\
(0.001)\end{array}$ & $\begin{array}{c}0.002 \\
(0.002)\end{array}$ & $\begin{array}{c}0.007 * * \\
(0.001)\end{array}$ & $\begin{array}{l}-0.001 \\
(0.002)\end{array}$ \\
\hline No. of Previous Deportations & $\begin{array}{l}-0.003 * \\
(0.001)\end{array}$ & $\begin{array}{l}0.002 * \\
(0.001)\end{array}$ & $\begin{array}{l}-0.001 \\
(0.003)\end{array}$ & $\begin{array}{c}-1.53 \mathrm{e}-04 \\
(0.003)\end{array}$ & $\begin{array}{l}-0.004 \dagger \\
(0.003)\end{array}$ \\
\hline Crossed without documents & $\begin{array}{l}-0.032^{*} \\
(0.013)\end{array}$ & $\begin{array}{l}-0.014 \\
(0.009)\end{array}$ & $\begin{array}{c}-0.037 * * \\
(0.012)\end{array}$ & $\begin{array}{c}0.027 * * \\
(0.010)\end{array}$ & $\begin{array}{c}0.005 \\
(0.019)\end{array}$ \\
\hline Crossed with a coyote & $\begin{array}{l}0.028^{*} \\
(0.012)\end{array}$ & $\begin{array}{l}0.051^{*} \\
(0.020)\end{array}$ & $\begin{array}{c}0.031^{* *} \\
(0.006)\end{array}$ & $\begin{array}{c}0.063 \\
(0.038)\end{array}$ & $\begin{array}{c}-0.041 * * \\
(0.015)\end{array}$ \\
\hline Duration of Last Spell (in Days) & $\begin{array}{c}-1.98 \mathrm{e}-06^{*} \\
(9.30 \mathrm{e}-07)\end{array}$ & $\begin{array}{c}-2.10 \mathrm{e}-06^{* * *} \\
(6.77 \mathrm{e}-07)\end{array}$ & $\begin{array}{l}-1.26 \mathrm{e}-06 \\
(2.89 \mathrm{e}-06)\end{array}$ & $\begin{array}{c}3.20 \mathrm{e}-05^{* *} \\
(5.83 \mathrm{e}-06)\end{array}$ & $\begin{array}{c}-1.03 \mathrm{e}-05^{* *} \\
(2.96 \mathrm{e}-06)\end{array}$ \\
\hline Observations & 23,631 & 23,650 & 23,631 & 13,172 & 23,649 \\
\hline R-squared & 0.068 & 0.067 & 0.095 & 0.461 & 0.254 \\
\hline
\end{tabular}

Notes: Regressions contain a constant as well as state FE, time FE and a state-time trend. S.E. (in parentheses) clustered at state level. ** p<0.01, * $\mathrm{p}<0.05, \dagger \mathrm{p}<0.1$

Data: 2005-2012 waves of the deported sample of the EMIF-Norte. 


\section{APPENDIX}

Table A

Operation Streamline and Omnibus Immigration Laws Dates

\begin{tabular}{|lll|}
\hline \multicolumn{3}{l}{ Panel A } \\
\hline Sector & Date Operation Streamline Started \\
\hline Del Rio & December 2005 \\
\hline Yuma & December 2006 \\
\hline Laredo & November 2007 \\
\hline Tucson & January 2008 \\
\hline El Paso & February 2008 \\
\hline Rio Grande Valley (McAllen) & June 2008 \\
\hline \multicolumn{3}{|c|}{ Panel B } \\
\hline State & \multicolumn{3}{l}{ Date of Enactment } \\
\hline Arizona & SB1070 & April 2010 \\
\hline Alabama & HB56 & June 2011 \\
\hline Georgia & HB87 & May 2011 \\
\hline Indiana & SB590 & May 2011 \\
\hline South Carolina & S20 & June 2011 \\
\hline Utah & H116, H466, H469, H497 & March 2011 \\
\hline
\end{tabular}

Source: Panel A: Lydgate, J. (2010). “Assembly Line Justice: A Review of Operation Streamline”. Earl Warren Institute Policy Brief, U. C. Berkeley.

Panel B: http://www.ncsl.org/documents/statefed/omnibus_laws.pdf. 